\title{
The Prehistoric Wetland Site of Náklo (Moravia, Czech Republic) - a Unique Piece of History
}

\author{
Alexandra Bernardováa ${ }^{a *}$, Jan Nováka, Vendula Vránová \\ ${ }^{a}$ Laboratory of Archaeobotany and Palaeoecology, Faculty of Science, University of South Bohemia, Branišovská 1760, 37005 České Budějovice, Czech Republic \\ ${ }^{b}$ Archaeological Centre in Olomouc, U Hradiska 42/6, 77900 Olomouc
}

\section{A RTICLE INFO}

\section{Article history:}

Received: $16^{\text {th }}$ November 2016

Accepted: $15^{\text {th }}$ May 2017

DOI: http://dx.doi.org/10.24916/iansa.2017.1.1

\section{Key words:}

plant macroremains

human impact

lowland wetland

Late Bronze Age

xylotomy

\begin{abstract}
A B S T R A C T
This paper summarises the results of an investigation from the former oxbow lake near the village Náklo. The study profile ("Náklo - Under the church") is situated near an archaeological site which is important due to the presence of pile constructions and a deposit of bronze vessels from the Halstatt Period. The study focused on the plant macroremains and xylotomy analysis. Only a few plant macroremains studies from lowland wetland sites are notable for the documented presence of archeophytes in central Europe. Our study confirmed long-term human impact and the important influence of human activities on the alluvial floodplain vegetation, especially during the Late Bronze Age and Hallstat Period. Our analysis of wood enabled the presence of alluvial forest with dominance of Salix, Populus, Alnus, and Ulmus to be reconstructed.
\end{abstract}

\section{Introduction}

The vegetation history and influence of human impact is usually reconstructed by pollen, plant macroremains and anthracological analysis, each method having its own advantages and/ordisadvantages. The research ofmacrofossils for documenting the impact of human settlement is usually limited to finds of charred macrofossils and thus the results are influenced by various factors or processes (taphonomy; Jacomet, Kreuz 1999). Uncharred plant macrofossils, on the other hand, due to the low possibilities of their preservation, are limited to rarely preserved wet sediments near to the archaeological site. In agricultural prehistory, the presence of uncharred plant macrofossils is usually restricted to human wells (e.g. Opravil 1983; 1984; Sedláček 2008). Thus every new wet locality, capable of chronologically recording the presence of uncharred macrofossils reflecting human impact, becomes very important.

Given the current state of archaeobotanical knowledge, we decided to focus our attention on a wetland locality situated in a former oxbow lake near the village Náklo. The name "Náklo" (or "Nákolí") is derived from the Czech word

*Corresponding author. E-mail: alex.bernardova@gmail.com describing "houses on piles", as the terrain was waterlogged and muddy. In literature from the end of $19^{\text {th }}$ century the locality was recorded as lying in a muddy area (Wankel 1889). The archaeological site is important not only for the presence of its pile constructions, but also by the find of bronze vessels from the Halstatt Period (Figure 1).

In this study, we focused on: 1) reconstruction of the vegetation in the close vicinity of the Náklo locality, based on plant macrofossils from the local wet sediments; 2) comparison of the record of wooden vegetation using xylotomy and analysis of macrofossils, and 3) comparison of our records, with regional archaeobotanical records.

\section{Materials and methods}

\subsection{Study area and present-day vegetation}

The village of Náklo is located at the edge of the flood plain of the Morava River, $14 \mathrm{~km}$ northwest of Olomouc, at an altitude of $225 \mathrm{~m}$ asl. It lies on an elevated loess terrace in the region of Litovelské Pomoraví (Figure 2).

The Litovelské Pomoraví is the northern part of the Upper Moravian Vale. The lowland is characterized by the presence of quaternary sediments such as loess, gravels and alluvial 


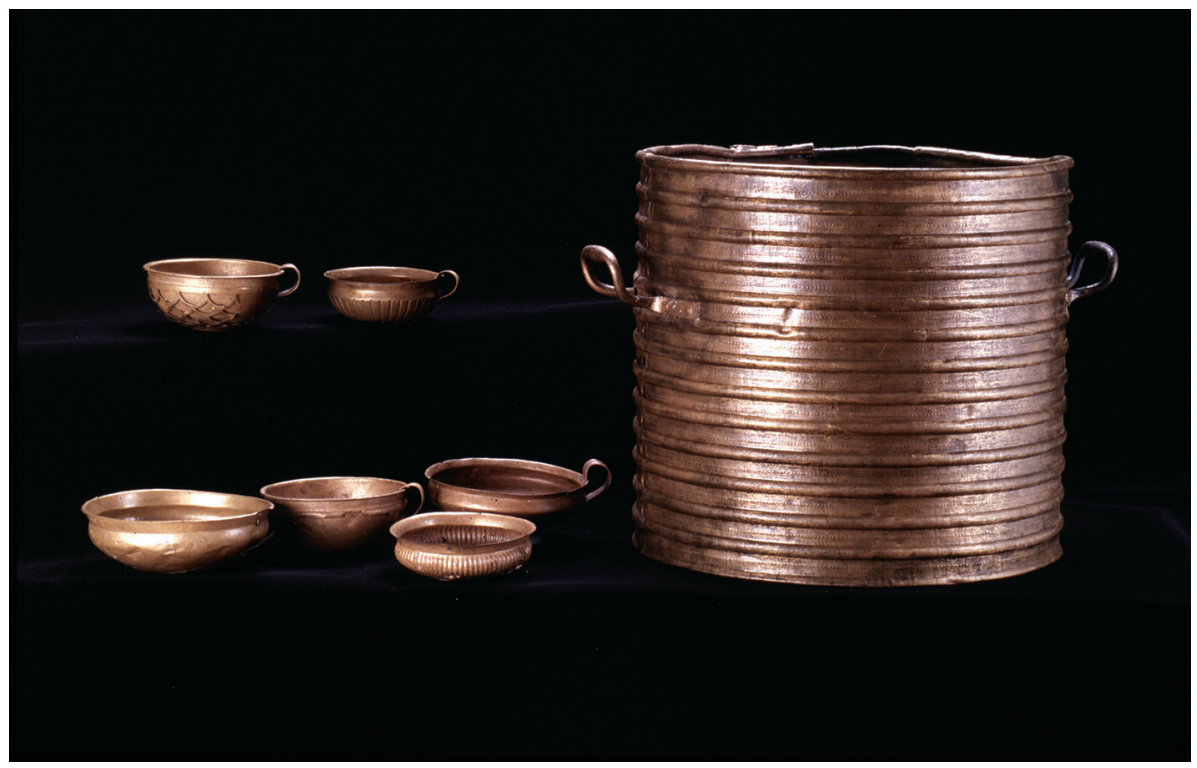

Figure 1. Unique find of a deposit of bronze vessels coming from the sediments, which could be dated to the Hallstatt Period, found at the beginning of the $20^{\text {th }}$ century.

sediments (Czudek 1972). Fluvisols and chernozem were mapped as the most common soils near Náklo village (AOPK 2005). The lowland area falls into the Thermophyticum phytogeographical region with a slightly dry and continental, central European climate. The mean annual precipitation is $550-600 \mathrm{~mm}$, and mean annual temperature $8.5-9^{\circ} \mathrm{C}$ (meteorological site: Olomouc; Quitt 1971).

At present, the lowland region is predominantly agriculturally managed with forests covering only a small percentage of the landscape. The current riverine forests belong to the Ulmenion alliance (Chytrý 2013), and the occurrence of Salix and Alnus is associated with river banks and wetlands. Oak-hornbeam forests (Carpinion) are typical of the drier part of the lowland, which hydrologically does not belong to the Morava river catchment. As potential natural vegetation, hardwood forests of lowland rivers (Ulmenion) and oak-hornbeam forests (un. Carpinion) have been recreated in the area (Neuhäuselová, 2001).

Litovelské Pomoraví is influenced by long-term agricultural management (Čižmářová et al. 1996). A lot of findings, including chronologically almost the whole of prehistory, the Middle Ages, and the Modern Period, have
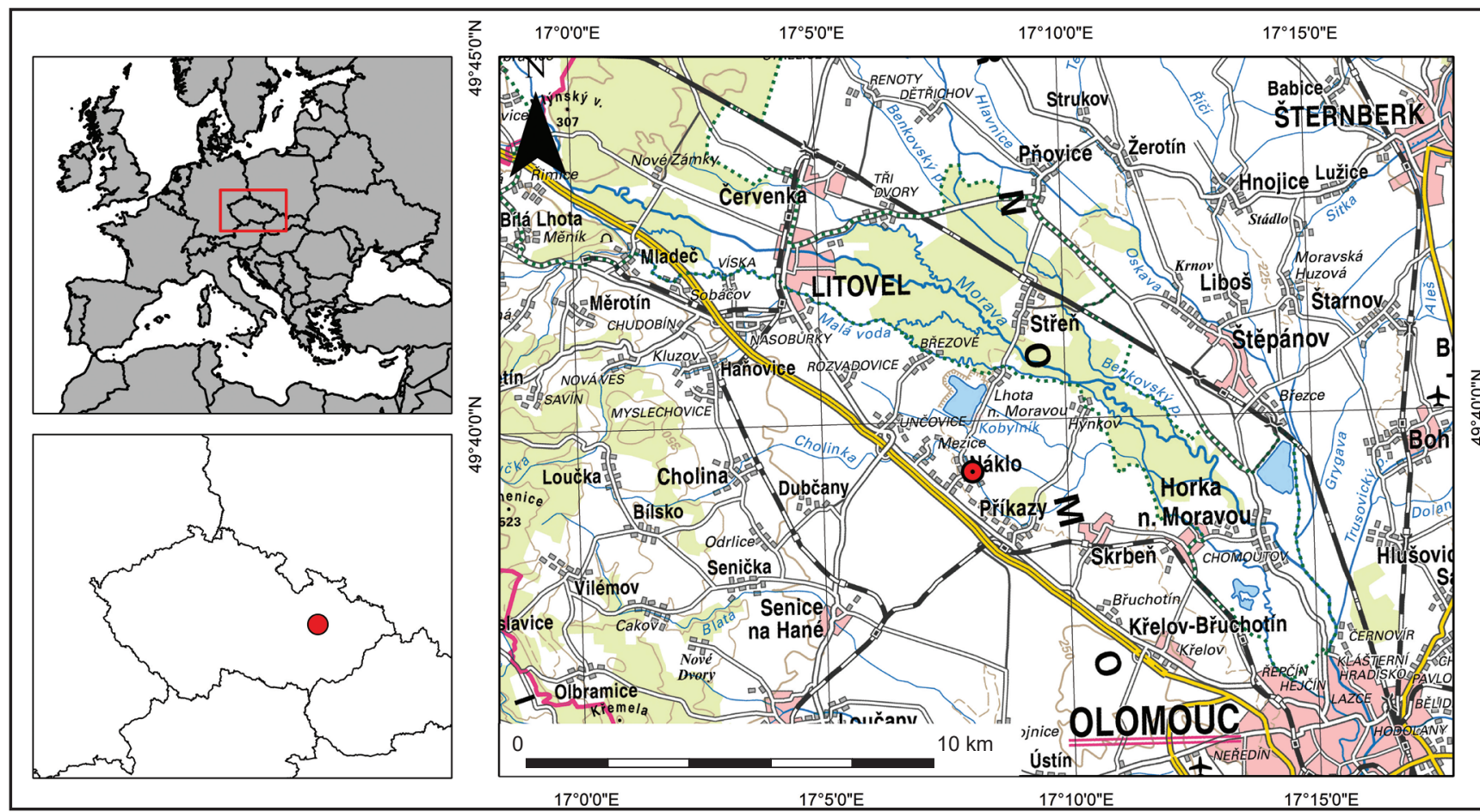

Figure 2. Location of the studied area. The circle marks the location of the trench where the sediement was retrieved. Source: https:/geoportal.gov.cz. 
Table 1. Sediment description of the soil profile.

\begin{aligned} & \hline $0-135$ Subrecent backfill \\ & $135-157$ Stone paving and sandy sediment \\ & $157-185$ Dark brown clay sediment and gravel layer \\ & $185-189$ Sandy layer \\ & $189-213$ Dark brown clay sediment and gravel layer with wood fragments \\ & $213-251$ Finely laminated sediment - sandy layers with higher or lower organic content \\ & $251-257$ Gravel and sandy layer \\ & $257-273$ Dark brown clay sediment and gravel layer \\ & $273-285$ Gravel and sandy layer \\ & \hline\end{aligned}

Table 2. Radiocarbon dates. The ${ }^{14} \mathrm{C}$ data were calibrated to calendar ages using the OxCal 4.2 online application (Bronk Ramsey 2009) based on the IntCal 13 (Reimer et al. 2013) calibration curve.

\begin{tabular}{ccllll}
\hline Depth $(\mathbf{c m})$ & BP & Lab code & cal BC/AD & Dated material & Archaeological period \\
\hline $201-204$ & $1800 \pm 50$ & Poz-65457 & $222 \pm 74$ AD & Sambucus sp. seeds & Roman Period \\
$234-231$ & $1770 \pm 30$ & Poz-62222 & $267 \pm 46$ AD & Sambucus sp. seeds & Roman Period \\
239 & $2538 \pm 84$ & CRL 8059 & $648 \pm 124$ BC & wood fragment & Iron Age (Hallstatt) \\
255 & $2613 \pm 84$ & CRL 8058 & $754 \pm 270 \mathrm{BC}$ & wood fragment & Late Bronze Age \\
$279-282$ & $2540 \pm 50$ & Poz-65458 & $673 \pm 99 \mathrm{BC}$ & Sambucus sp. seeds & Late Bronze Age \\
\hline
\end{tabular}

been obtained up to the present (e.g. Čižmář, Kohoutek 1999; Oliva 2003; Peška 2001; Wankl 1889). Among the periods of greatest population density, we can include, for example, the period of the Linear Pottery Culture (7550-6850 cal BP), Late Eneolithic (4850-4450 cal BP), or the Late Bronze Age (3250-2750 cal BP).

\subsection{Methods}

A $285 \mathrm{~cm}$ long sediment profile was recovered from a trench near the place known locally as "Under the church" (N 49³9'20.3" E $17^{\circ} 08^{\prime} 03.4^{\prime \prime}$ ) using Kubiena tins $(50 \times 10 \times 10 \mathrm{~cm})$. Wood trunks, twigs and branches were sampled separately during the recovery of the sediment. Slices were cut from big trunks. The profile was then sedimentologically described, and subsampled at regular intervals of $3 \mathrm{~cm}$. Sediment samples were washed through $0.25 \mathrm{~mm}$ sieves. Macroscopic remnants were picked out and identified with the help of a reference collection and determination literature, e.g. Anderberg (1994), Berggren (1981) and Cappers et al. (2006). Pollen analyses from the samples were not carried out, as the sediment was sandy and the pollen concentration of several tested samples was very low and unrepresentative. A study from another Moravian locality Únanovka encountered a similar problem (Petřík et al. 2015).

Macrofossil diagrams were created in the Tilia program (Grimm 2011). The nomenclature follows the determination key to the Czech flora (Kubát et al. 2002).

Wood fragments were identified with the help of a reference collection and standard identification keys (Greguss 1972; Schweingruber 1990) using a light microscope with 200-500× magnification. The wood fragments were quantified as the number of analysed fragments.
Plant macrofossils were used for AMS radiocarbon dating in the Poznań Radiocarbon Laboratory. For the radiocarbon dating of wood fragments, samples were sent to the CRL Radiocarbon Laboratory of the Nuclear Physics Institute, $\mathrm{CAS}$. The ${ }^{14} \mathrm{C}$ data were calibrated to calendar ages using the OxCal 4.2 online application (Ramsey 2009) based on the IntCal 13 (Reimer et al. 2013) calibration curve.

\section{Results}

\subsection{Sediment description}

The length of the core was $285 \mathrm{~cm}$. The regular changing of sandy layers with organic-rich sandy sediments is obvious. The base layer was built up of a gravel flood layer. Gravel layers were followed by silt layers containing high or low amounts of an organic part, creating a laminated design. The upper $157 \mathrm{~cm}$ were built up of recent sediments used for building modern paving made up of stones and bricks. For a detailed description see Table 1.

\subsection{Sediment dating}

The studied sediment covered the period from the Late Bronze Age to High Middle Age (285-157 cm). The upper part was contaminated by a recent mixture of various origins that had been used for building the modern brick paving. At the bottom layer, sherds of Late Bronze Age were found and the age was also proved by dating $(2623 \pm 99$ cal BP, depth 279-282 cm). Shards dated to High Middle Age were present right under the brick paving. Radiocarbon dates are presented in Table 2. 


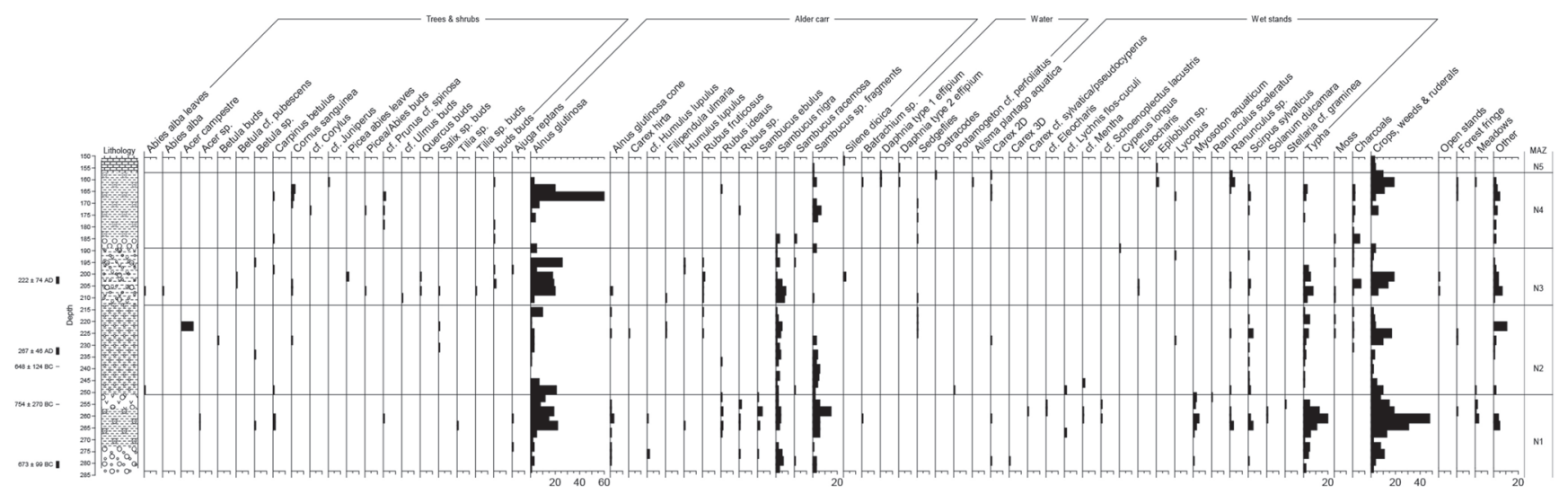

Figure 3. Macrofossil diagram. Trees and shrubs, wet stands and water and alder carr species are plotted in absolute values.

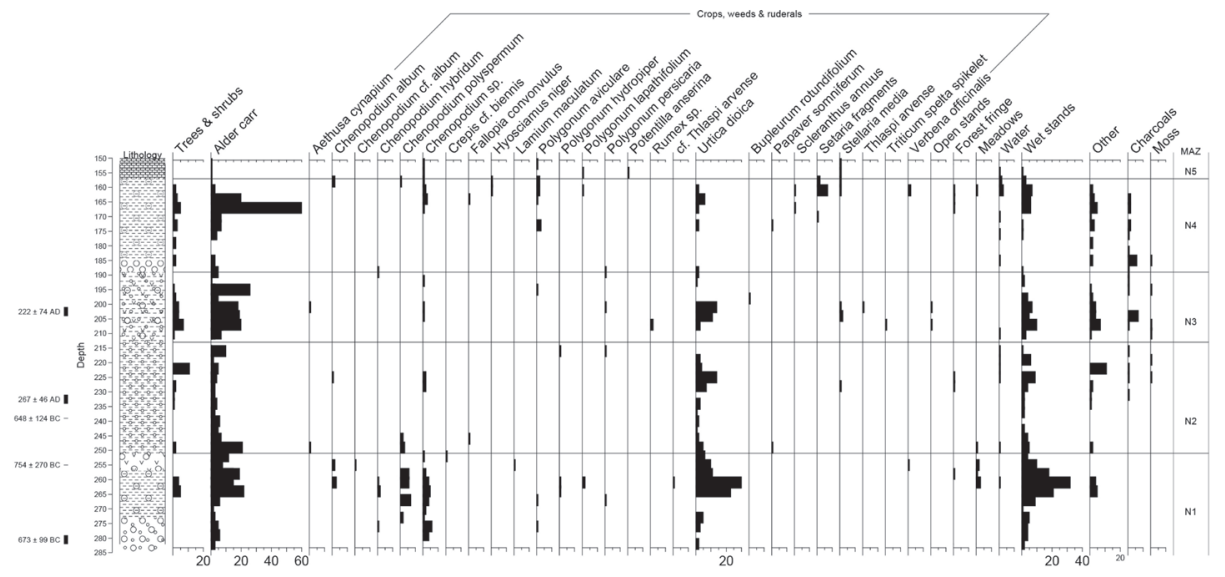

Figure 4. Macrofossil diagram. Species of crops, weeds and ruderals are plotted in absolute values.

\subsection{Analysis of macrofossils}

According to the character of the analysed sediment the profile could be divided into five macrofossil zones (N1-N5; Figures 3 and 4).

Late Bronze Age, zone N1 $(285-251 \mathrm{~cm})$ is built up of two types of sediment. The gravel terrace at the bottom of the profile is characterised by high frequencies of Sambucus nigra, S. ebulus, Alnus glutinosa, Chenopodium sp., Typha sp., Urtica dioica, Humulus lupulus, Polygonum aviculare agg., Persicaria maculosa, P. hydropiper, and Rubus sp. seeds. Only a few wetland or alder carr species (Carex sp., Scirpus sylvaticus and Myosoton aquaticum) were sporadically documented in this layer. The following brown clay layer, with a higher presence of organic material, is distinguished by higher frequencies of wetland (Schoenoplectus lacustris, Typha sp., Ranunculus scelaratus, cf. Mentha, Carex sp., Scirpus sylvaticus, Filipendula ulmaria, and Solanum dulcamara) and aquatic species (Potamogeton cf. perfoliatus, and Batrachium sp.). The clay layer also contained many seeds of plants characteristic of meadows, fields, and ruderal habitats (e.g. Hypericum perforatum, Prunella vulgaris, Campanula sp., Ajuga reptans, Verbena oficinalis, Carduus sp., Papaver somniferum, Crepis cf. biennis, Crepis cf. tectorum, Polygonum aviculare agg., Fallopia convolvulus, and Chenopodium sp.). In contrast to the gravel sediments, this layer also documented the abundant presence of species characteristic of alder carr and alluvial habitats (Alnus glutinosa, Sambucus nigra, S. ebulus, Rubus ideaus and Rubus sp., Urtica dioica, Myosoton aquaticum and Humulus lupulus). A high number of twigs, branches and tree trunks were recorded at the depth 257-251 cm (Abies alba, Carpinus betulus, Betula sp., Prunus cf. spinosa and Tilia sp.).

Zone N2 (251-212 cm, Halstatt/Roman period) is built up of laminated sandy sediments. The content of macrofossils is relatively poor. However, Alnus glutinosa, Sambucus nigra, Typha sp., Filipendula ulmaria, Carex sp., Lycopus europaeus and Scirpus sylvaticus seeds are still frequent. Some macroremains of trees (Acer campestre, Cornus sanguinea, Betula sp. and Salix sp.) were also recorded here.

Zone N3 (212-185 cm, Roman period) is distinguished from the previous layer by the higher presence of clay sediments and higher quantity of plant macroremains. There are scarce occurrences of cereals - Triticum spelta (spikelet fork), weeds and ruderals (Bupleurum rotundifolium, Chenopodium sp. and Thlaspi arvense). The presence of water bodies (periodical or permanent) are documented by the stable presence of sedgeflies larvae protective cases. Zone N3 also documented some peaks of charcoal 
fragments. Besides the abundant presence of Alnus glutinosa and Sambucus sp. seeds, several other trees and shrubs were recorded in this layer (Quercus sp., Tilia sp., Ulmus sp., Carpinus betulus, Cornus sanguinea, Betula sp., Abies alba and Picea abies), which points to the gradual formation of riparian forest with water bodies.

Zone N4 (185-157 cm, Early-High Middle Ages) recorded the common presence of alder carr species (Alnus glutinosa, Sambucus nigra, Scirpus sylvaticus, Rubus ideaus, Lycopus europaeus and Urtica dioica), but also the higher occurrence of shrubs (Cornus sanguinea, Corylus avellana, cf. Juniperus and Prunus cf. spinosa), ruderals and weeds (Hyoscyamus niger, Chenopodium sp., Polygonum aviculare agg., Potentilla anserina, Falopia convolvulus, Scleranthus annuus, Verbena officinalis, Setaria sp., Stellaria media and Papaver somniferum). A peak of charcoal fragments is documented. The presence of aquatic plants (Batrachium sp.), Daphnia resting eggs, Ostracoda shells and sedge fly protective cases documented the presence of water bodies (at least periodical).

High Medieval zone N5 $(157-150 \mathrm{~cm})$ was sharply delimited by the abrupt change of sediment character. Only macrofossils of ruderals, such as Stellaria media, Polgonum aviculare agg. and Chenopodium sp., were present.

\subsection{Analysis of wood}

Xylotomy samples from the Náklo profile recorded the presence of alluvial vegetation, which is connected with river oxbow development in the Bronze Age and Roman Period (Figure 5). A high number of twigs, branches and tree trunks were determined from the layer $257-251 \mathrm{~cm}$ (zone N1). This layer was characterised by a dominance of Populus/Salix (63\%), high abundance of Alnus (21\%) and Ulmus (10\%). The presence of Pomoideae, Prunus cf. padus and Acer was only sporadic $(2 \%)$.

\section{LAYER 257-251 CM - WOOD FRAGMENTS}

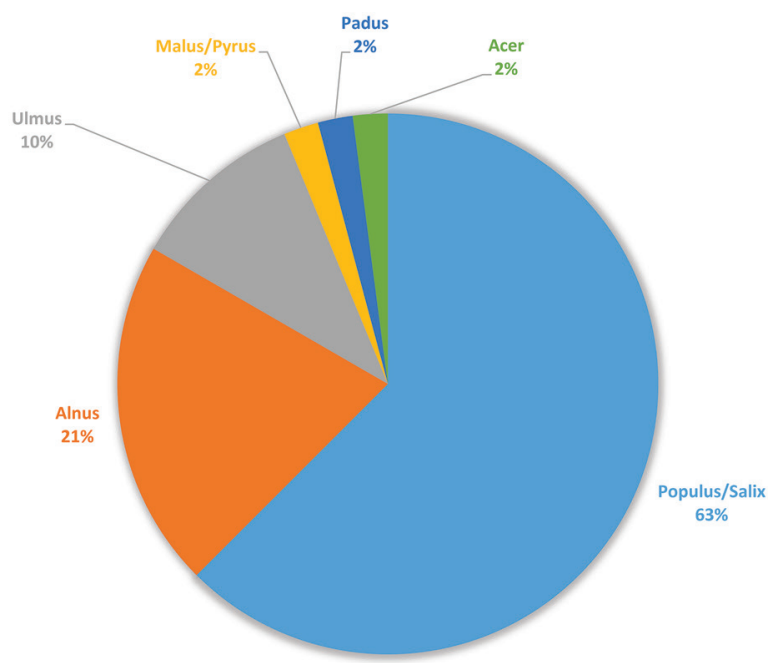

Figure 5. Species of wood (twigs, branches) found in accumulation layer $251-257 \mathrm{~cm}$.
The layer N2 (Late Bronze Age/Hallstat) was characterised by the presence of Populus, Ulmus and Pomoideae trunks, and layer N3 (Roman Period) contained an analogous composition of tree trunks (Populus, Salix and Ulmus).

\section{Discussion}

\subsection{Historical context}

Floodplain or alluvial sites were readily suitable for human activities. According to Quitta (1969) floodplains were more open and thus easier to walk over than the oak hornbeam forests. However, similarly-studied localities with prehistoric settlements are very scarce in central Europe. In the CZAD - Archaeobotanical database of the Czech Republic (Pokorná et al. 2011), there are several records of archaeological sites in the Litovelské Pomoraví region where archaeobotanical research has been undertaken. There is the Neolithic settlement in Mohelnice (Opravil 1979a; 1979b), the Eneolithic site Moravičany (Kühn 1981), La Tène site Řepčín (Kalábek, Kočár 2006), and analogous wetland sites with preserved macrofossils - Early Medieval Mikulčice (Opravil 1972; 1983; 2000; Latková, Hajnalová 2014) - or sediments from the well in Dražkovice dated to the Roman Period (Sedláček et al. 2008). An important wet locality is the pre-Roman Age hill-fort Vladař (Pokorný et al. 2006).

In the context of central Europe, there are very important lake dwellings in the circumalpine region. The history of their excavation is more than 150 years old and a lot archaeobotanical work has been done so far, especially in Germany and Switzerland (e.g. Brombacher 1997; Hosch, Jacomet 2001; Liese-Kleiber 1997; Menotti 2004). Several studies of alluvial sediments also come from other countries, such as Slovenia (e.g. Tolar 2010) or Bulgaria (Popova 2013).

\subsection{Plant macrofossils records}

The study profile is distinguished by alternate layers of clay, and sand or gravel, sediment. The abundance of plant macrofossils was much higher in the clay layers, connected with the quieter sedimentation in the oxbow lake. The gravel or sand sedimentation probably documented more rapid flood sedimentation. Our profile documented four periods with quiet sedimentation and four with sandy or gravel sedimentation during the period from Late Bronze Age to High Medieval. The macrofossil analysis recorded the presence of alder carr species in all the zones except the last one (N5). The transport of seeds during a quiet sedimentation period was probably reduced and the species composition recorded that of vegetation near an oxbow lake (Brown 1997).

Weeds and ruderals, considered as evidence of human presence, were most abundant in the Late Bronze Age zone N1 (3250-2750 cal BP). Clay layers also documented many species characteristic of meadow, ruderal or segetal (grainfield) vegetation. The presence of these species should relate to the archaeological site, which was near the wetland. Similar records of nearby human settlement have been 
documented in alluvial sediments in Mohelnice dated to the Neolithic, the Eneolithic locality Moravičany, or the La Tène site Řepčín where anthropogenic indicators were present in considerable amounts (Opravil 1979a; 1979b; Kühn 1981; Kalábek, Kočár 2006). The long-term systematic research of the River Morava cut-off at the Early Medieval site in Mikulčice has also documented assemblages of crops and other cultivated plants, as well as wild plant communities (Opravil 1972; 1983; 2000; Latková, Hajnalová 2014).

The rarity of crops and abundance of local species probably indicates non-intensive cultivation supplemented by foraging (Moffet et al. 1989). From the presence of weedy species, we can infer a pastoral economy in the vicinity of the site (Murphy 1997).

Seeds of Sambucus sp. and Rubus sp. were abundant throughout the whole profile. This can be explained by the occurrence of these species in the alder carr, but also taken as proof of human settlement or activities in the area. In the literature, Sambucus and Rubus is usually presented as species proving forest clearance (e.g. Tóth et al. 2009); however, these plants are also documented as being widely used (collected) since the Mesolithic (Divišová, Šída 2015). Moreover, the seeds of both species have hard and lignified outer layers, which helps their preservation in the sediment. Similarly, we could assume a high presence of Urtica dioica seeds, which, on the one hand, is a typical representative of alder carr species. On the other hand, a recent study from Denmark has suggested nettles as an important Bronze Age plant exploited for textile production in their natural habitat (Bergfjord et al. 2012). Chenopodium album agg. (or Chenopodium sp.) is a widely-distributed ruderal species very often reported from archaeobotanical samples, usually followed by Polygonum species (P. lapathifolium, P. persicaria, $P$. hydropiper). Considering their frequent occurrence in cultural contexts it is possible that some parts of these plants (leaves, roots, seeds) were used as some form of food complement (e.g. Popova 2013); however, proving edibility is difficult so their dietary importance is usually neglected (Colledge, Conolly 2014).

Zones N2 and N3 cover the Iron Age (2750 to $1600 \mathrm{cal}$ $\mathrm{BP})$. During this time, the erosion of fine material from the unprotected surface and the accumulation of colluvial and fluvial sediments took place (Mackel 2003). The Alnus decline is obvious in zone $\mathrm{N} 2$, which could be connected either with human activity or with the natural cycle of alder carr (Pokorný et al. 2000). Even though no direct archaeological evidence of human presence was found during the excavation of the sediment, seeds of weeds and crops - Chenopodium sp., Polygonum persicaria, Fallopia convolvulus, Papaver somniferum or Triticum spelta point to nearby arable land.

Out of all the 42 species found in the profile, eight of them are considered archaeophytes - species introduced accidentally before the year 1492, most probably with agriculture: Bupleurum rotundifolium; Chenopodium album; Crepis cf. tectorum; Fallopia convonvulus; Papaver somniferum; Sambucus ebulus; Thlaspi arvense; and Verbena officinalis (Pyšek et al. 2012). Chenopodium album,
Fallopia convonvulus and Thlaspi arvense are found within samples since the Neolithic in central Europe. Seeds of poppy (Papaver somniferum) have been found only scarcely in prehistoric samples so far, with the oldest finds dated to the Eneolithic and Late Bronze Age. After the onset of the Bronze Age and Iron Age, these seeds became more frequent (Kočár, Dreslerová 2010).

According to the macrofossil database CZAD (Pokorná et al. 2011), there are several finds of species whose presence in such old layers are unique, for example, Auethusa cynapium and Verbena officinalis are reported from the Middle Ages only.

The presence of humans is also indicated by the increasing number of charcoal fragments (Ohlson, Tryterud 2000). The above-mentioned La Tène site Řepčín (Kalábek, Kočár 2006) is located about $10 \mathrm{~km}$ far away.

In zone N4, which covers the Middle Ages, anthropogenic impact is documented by the high presence of charcoal pieces and anthropogenic indicators typical for trampled places (Scleranthus annuus, Polygonum aviculare agg. and Stellaria media). Human activities in the area are very probable in this period (Opravil 1983).

\subsection{Reconstruction of the woodland vegetation}

Xylotomy analysis recorded a dominance of floodplain trees (Salix/Populus, Alnus) and the presence of Ulmus and Pomoidea. Such a species spectrum is characteristic of floodplain vegetation (Salicion albae) situated along river banks and wetlands in the vicinity of oxbow lakes (Chytrý et al. 2013). This vegetation type was probably relatively scarce and restricted to just a small percentage of habitats in the landscape. This assumption has been confirmed by many xylotomy and anthracological analyses from the Litovelské Pomoraví region (e.g. Opravil 1983; Novák et al. 2017; Kočár, Kočárová, in press).

The woodland vegetation of the Litovelské Pomoraví region has been characterized as a stable continuity of species-rich deciduous forest with a dominance of Quercus, a very common presence of Fraxinus and Ulmus, and a less-common presence of Corylus, Acer and Pomoideae during its whole agricultural prehistory (Novák et al. 2017). The presence of Carpinus is commonly recorded since the Bronze Age. The occurrence of Fagus and Abies has also been recorded since the Bronze Age, but their abundance was low throughout our study period. Alnus and Populus/ Salix charcoal was commonly recorded throughout the agricultural prehistory, but their abundance was commonly lower. The higher percentage abundance of Alnus and Populus/Salix charcoal pieces has been documented from archaeological sites within the vicinity of rivers or wetlands (Novák et al. 2017). An analogous species spectrum with dominance of Quercus, Fraxinus, Ulmus and Tilia woodland from localities in the vicinity of the Morava River has also been recorded during the Early and High Middle Ages (Opravil, 1983).

A comparison of anthracological results with our xylotomy records suggests that our record from the Náklo 
profile is closely local. We suggest that the presence of the willow-poplar-alder vegetation was restricted to the vicinity of oxbow wetlands, river banks and riverbeds.

If we compare the results of xylotomy and plant macroremains analysis, we can see the dominance of Alnus. This result could be affected by the large production and good preservation of Alnus seeds. The macrofossil analysis also documented the presence of Sambucus, Carpinus, Tilia, Ulmus, Quercus, Acer, Betula, Cornus sanguinea, Salix, Prunus, Corylus, Abies, Picea and Juniperus. Most of these trees usually grow outside wetland areas and their seeds were probably transported to the oxbow lake sediment from the surrounding landscape vegetation. The oxbow lake was connected with the Cholinka stream and the presence of the trees recorded was probably commonly spread throughout its catchment. The gravel layers in the study profile draw attention to the occurrence of floods probably connected with the Morava River. We cannot exclude the possibility that some of the seeds originated from the wider area of the Morava River catchment (Petř́k et al. 2015).

The Middle and Upper Holocene pollen records from the central Moravia region (Novák et al. 2017) have been characterized by an abundant presence of Pinus, Picea, Tilia, Alnus, common spread of Betula, Corylus, Abies, Salix, and only some scarce records of Quercus, Fraxinus, Ulmus, Acer, Fagus, Carpinus and shrubs. Many studies have documented how pollen assemblages can be influenced by pollen productivity, pollen dispersal, pollen taphonomy and the spatial structure of source plants around the pollen site (e.g. Nielsen, Odgaard 2005; Sugita 2007); the pollen spectra from any natural archive contains both a local and regional component. Appropriate pollen localities in the central Moravia region have been described as very small wetlands (Novák et al. 2017). These small pollen sites are surrounded by a closed canopy and the signal from local vegetation in their vicinity would therefore prevail (e.g. Sugita 2007). Although the pollen and our xylotomy analyses were performed from analogous types of habitats (usually former oxbow lakes), we can see many differences in woodland composition. Many of these differences are probably connected with the distinct history of the local vegetation. However, the high pollen signal of Pinus and Picea is probably caused by the high pollen production and easy pollen dispersal (e.g. Pohl 1937; Andersen 1974).

\section{Conclusion}

The profile is situated at the edge of the village of Náklo and was recovered close to its development area as exemplified by the fragments of pottery found in the profile dated to the Bronze Age -Hallstatt Period and High Middle Ages. The area of Náklo was influenced by the Morava River, whose influence remained in the form of a cut-off meander which was called "the horseshoe". In our study, we have proved the impact of humans in the Late Bronze Age, Hallstatt Period and Roman Empire, and in the High Middle Ages, which correspond with the archaeological findings. The studied profile not only reflects human settlement, but the natural environment itself directly in the alluvial floodplain.

\section{Acknowledgements}

We would like to thank our colleagues during the fieldwork (Tereza Šálková, Martin Pták, Tomáš Bešta, Milan Aldorf and Zdeněk Vaněček) and to Jiří Bumerl for producing the map. Our research was supported by grant GAČR 13-11193S from the Czech Science Foundation and project PAPAVER - Centre for human and plant studies in Europe and Northern Africa in the postglacial period, reg. No. cz.1.07/2.3.00/20.0289.

\section{References}

ANDERBERG, A. L. 1994: Atlas of Seeds and Small Fruits of NorthwestEuropean Plant Species with Morphological Descriptions. Swedish Museum of Natural History, Stockholm.

ANDERSEN, S.T. 1974: Wind Conditions and Pollen Deposition in a Mixed Deciduous Forest. Grana 14, 57-63.

AOPK 2005: Soil Maps of the Czech Republic 1:50 000. Praha: Agentura ochrany prírody a krajiny, Czech Geological Survey.

BERGGREN, G. 1981: Atlas of Seeds and Small Fruits of NorthwestEuropean Plant Species with Morphological Descriptions. Swedish Museum of Natural History, Stockholm.

BERGFJORD, C., MANNERING, U., FREI, K. M., GLEBA, M., SCHARFF, A. B., SKALS, I., HEINEMEIER, J., NOSCH, L. M., HOLST, B. 2012: Nettle as a distinct Bronze Age textile plant. Scientific Reports 2, article code 664 .

BROMBACHER, C. 1997: Archaeobotanical investigations of Late Neolithic lakeshore settlements (Lake Biel, Switzerland). Vegetation History Archaeobotany 6, 167-186.

BROWN, A.G. 1997: Alluvial Geoarchaeology: Floodplain Archaeology and Environmental Change. Cambridge University Press, Cambridge.

CAPPERS, R. T. J., BEKKER, R. M., JANSET, J. E. A. 2006: Digital Seed Atlas of the Netherlands. Groningen, Institute of Archaeology and the Deutsches Archäologisches Institut, Groningen.

CHYTRÝ, M. 2013: Vegetation of the Czech Republic 4. Forest and scrub vegetation. Academia, Praha.

ČIŽMÁ̌̌, Z., KOHOUTEK, J. 1999: Přerov - Horní náměstí. Výstavba dvou obytných domů. MS. Excavation report No. 29/99. Deposited: ÚAPP Brno, Czech Republic.

ČIŽMÁŘOVÁ J., ONDRUŠ V., SALAŠ M. et al. 1996: Pravěk Moravy. Moravské zemské museum, Brno.

COLLEDGE, S., CONOLLY, J. 2014: Wild plant use in European Neolithic subsistence economies: a formal assessment of preservation bias in archaeobotanical assemblages and the implications for understanding changes in plant diet breadth. Quaternary Science Reviews 101, 193-206. CZUDEK, T. 1972: Geomorfologické členění ČSSR. Studia Geographica 23.

DIVIŠOVÁ, M., ŠÍDA, P. 2015: Plant use in the Mesolithic period. Archaeobotanical data from the Czech Republic in a European context - a review. Interdisciplinaria Archaeologica - Natural Sciences in Archaeology VI/1/2015, 95-106.

GREGUSS, P. 1972: Xylotomie of the Living Conifers. Akademiai Kiado, Budapest.

GRIMM, E., C. 2011: Tilia 1.7.16 Software. Illinois State Museum, Research and Collection Cente, Springfield.

HOSCH, S., JACOMET, S. 2001: New aspects of archaeobotanical research in central European Neolithic lake dwelling sites. Environmental Archaeology 6, 59-71.

JACOMET, S., KREUZ, A. 1999: Archäobotanik. Aufgaben, Methoden und Ergebnisse vegetations- und agrargeschichtlicher Forschung. Ulmer, Stuttgart. 
KALÁBEK, M., KOČÁR, P. 2007: Laténský objekt s nálezy obilí z lokality Olomouc-Řepčín 1. Pramen k poznání zemědělství v mladší době železné. In: Bém, M., Peška, J. (Eds.): Ročenka 2006, Archeologické centrum Olomouc, Olomouc, 94-125.

KOČÁR, P., DRESLEROVÁ, D. 2010: Archeobotanické nálezy pěstovaných rostlin v pravěku České republiky (Archaeobotanical finds of cultivated plants in the prehistory of the Czech Republic). Památky archeologické 101, 203-242.

KOČÁR, P., KOČÁROVÁ R. In press: Př́rodní prostředí a ekonomika raně středověkého sídliště v Přerově. In: Procházka, R. (Ed.): Přerov, Horni náměstí č.p. 8, 9 a 21. Raně středověké osidleni do poloviny 11. století. Spisy Archeologického ústavu AV ČR Brno Institute of Archaeology of the Academy of Sciences of the Czech Republic, Brno.

KÜHN, F. 1981: Rozbory nálezů polních plodin. Přehled výzkumů 1979, 75-79.

KUBÁT, K., HROUDA, L., CHRTEK, J. jr., KAPLAN, Z., KIRSCHNER, J., ŠTĚPÁNEK, J. (Eds.) 2002: Klič ke květeně České republiky. Academia, Praha.

LÁTKOVÁ, M., HAJNALOVÁ, M. 2014: Plant macro-remains from the palaeochannel sediments in Mikulčice, trench B 2012. In: Poláček, L. (Ed.): Mikulčice river archaeology. New interdisciplinary research into bridge No. 1. Institute of Archaeology of the Academy of Sciences of the Czech Republic, Brno, 93-112.

LIESE-KLEIBER, H. 1993: Settlement and landscape history at the Federsee, south-west Germany, as reflected in pollen diagrams. Vegetation History and Archaeobotany 2/1,37-46.

MÄCKEL, R., SCHNEIDER, R. AND SEIDEL, J. 2003: Anthropogenic impact on the landscape of Southern Badenia (Germany) during the Holocene-documented by colluvial and alluvial sediments. Archaeometry 45/3, 487-501.

MENOTTI, F. 2004: Living on the lake in prehistoric Europe: 150 years of lake-dwelling research. London, Routledge.

MOFFETT, L., ROBINSON, M., STRAKER, V. 1989: Cereals Fruit and Nuts: Charred Plant Remains from Neolithic Sites in England and Wales and the Neolithic Economy. In: Milles, A., Williams, D., Gardner, N. (Eds.): The Beginnings of Agriculture. British Archaeological Report (International Series) 496, Oxford, 243-261.

MURPHY, P. 1997: Fenland management project: Plant macrofossils. Chappells field, Deeping St. James, Lincolnshire. Ancient monument laboratory report 1/97.

NEUHÄUSLOVÁ Z., BLAŽKOVÁ D., GRULICH V., HUSOVÁ M., CHYTRÝ M., JENÍK J., JIRÁSEK J., KOLBEK J., KROPÁČ Z., LOŽEK V., MORAVEC J., PRACH K., RYBNÍČEK K., RYBNÍČKOVÁ E., SÁDLO J. 1998: Mapa potenciálni prírozené vegetace České republiky. Textová část. Academia, Praha.

NIELSEN, A. B., ODGAARD, B. V. 2005: Reconstructing land cover from pollen assemblages from small lakes in Denmark. Review of Palaeobotany and Palynology 133/1-2, 1-21.

NOVÁK, J., ABRAHAM, V., KOČÁR, P., PETR, L., KOČÁROVÁ, R., NOVÁKOVÁ, K., HOUFKOVÁ, P., JANKOVSKÁ, V., VANĚČEK, Z. 2017: The Middle and Upper Holocene woodland history in central Moravia (Czech Republic) reveals biases of pollen and anthracological analysis. The Holocene 27/3, 349-360.

OHLSON, M., TRYTERUD, E. 2000: Interpretation of the charcoal record in forest soils: forest fires and their production and deposition of macroscopic charcoal. The Holocene 10/4, 519-525.

OLIVA, M. 2003: Pohřebiště kromañoncĩ v Mladečských jeskynich. Archeologické centrum Olomouc, Olomouc 2003.

OPRAVIL, E. 1972: Rostliny z velkomoravského hradiště v Mikulčicích. Studie AÚ ČSAV Brno I/2. Praha.

OPRAVIL, E. 1979a: Rostlinné zbytky z Mohelnice 1. Časopis Slezského muzea A28, 1-13.

OPRAVIL, E. 1979b: Rostlinné zbytky z Mohelnice 2. Časopis Slezského muzea A28, 97-109.

OPRAVIL, E. 1983: Údolni niva v době hradištní. (ČSSR-povodí Moravy a Poodrí). Academia, Praha.

OPRAVIL, E. 1984: Poznámky k rekonstrukci př́rodního prostředí v neolitu ČSSR. Sbornik prací Filozofické fakulty brněnske univerzity E 29, 167-178.
OPRAVIL, E. 2000: Zur Umwelt des Burgwalls von Mikulčice und zur pflanzlichen Ernährung seiner Bewohner. In: Poláček, L. (Ed.): Studien zum Burgwall von Mikulčice IV. Institute of Archaeology of the Academy of Sciences of the Czech Republic, Brno, 9-169.

PEŠKA, J. 2001: Archeologické lokality a nálezy na katastru obce Náklo a Mezice. Střední Morava 13, 78-108.

PETŘíK, J., PETR, L., ŠABATOVÁ, K., DOLÁKOVÁ, N., LUKŠÍKOVÁ, H., DOHNALOVÁ, A., CHADIMOVÁ, L., BLAŠKO, D., MILO, P. 2015: Reflections of Prehistoric and Medieval human activities in floodplain deposits of the Únanovka Stream, South Moravia, Czech Republic. Zeitschrift für Geomorphologie 59/3, 393-412.

POHL, F. 1937: Die pollenerzeugung der Windblütler. Beihefte zum Botanischen Centralblatt 56A, 365-470.

POKORNÁ, A., DRESLEROVÁ, D., KŘIVÁNKOVÁ, D. 2011: Archaeobotanical Database of the Czech Republic, an Interim Report. Interdisciplinaria Archaeologica - Natural Sciences in Archaeology II/1/2011, 49-53.

POKORNÝ, P., KLIMEŠOVÁ, J., KLIMEŠ, L. 2000: Late holocene history and vegetation dynamics of a floodplain alder carr: A case study from eastern Bohemia, Czech Republic. Folia Geobotanica 35/1, 43-58.

POKORNÝ, P., BOENKE, N., CHYTRÁČEK, M., NOVÁKOVÁ, K., SÁDLO, J., VESELÝ, J., KUNEŠ, P., JANKOVSKÁ, V. 2006: Insight into the environment of a pre-Roman Iron Age hillfort at Vladar, Czech Republic, using a multi-proxy approach. Vegetation History and Archaeobotany, 15/4, 419-433.

POPOVA, T. 2013: Palaeobotanic analysis in the region of the town of Septemvri-Pistiros and its neighbourhood. In: Bouzek, J., Domaradzka, L., Archibald, Z. H. (Eds.): Pistiros V: Excavations and Studies. Prague, 255-263.

PYŠEK, P., CHYTRÝ, M., PERGL, J., SÁDLO, J., WILD, J. 2012: Catalogue of alien plants of the Czech Republic ( $2^{\text {nd }}$ edition): checklist update, taxonomic diversity and invasion patterns. Preslia $84,155-255$.

QUITT, E. 1971: Klimatické oblasti Československa. Academia, Praha.

QUITTA, H. 1969: Zur Deutung bandkeramischer Siedlingsfunden aus Auen und grundwassernahen Standorten. In: Otto, K. H., Herrman, J. (Eds.): Siedlung, Burg und Stadt. Deutsche Akademie der Wissenschaften zu Berlin, Schriften der Sektion für Vor- und Frühgeschichte 25, Berlin, $42-55$.

RAMSEY, C.B. 2009: Bayesian analysis of radiocarbon dates. Radiocarbon $51 / 1,337-360$.

REIMER, P. J., et al. 2013: IntCal13 and Marine13 Radiocarbon Age calibration curves 0-50,000 years cal BP. Radiocarbon 55/4, 1869-1887.

SCHWEINGRUBER, F.H. 1978: Microscopic Wood Anatomy. Swiss Federal Institute of Forestry Research, Birmensdorf.

SEDLÁČEK, R., BENEŠ, J., ČEJKOVÁ, A., KOLÁŘ, T., KOMÁRKOVÁ, V., KYNCL, T., NOVÁK, J., NOVÁKOVÁ, K., SVĚTLÍK, I. 2008: The well from Dražkovice by Pardubice: complex archaeological and archaeobotanical analysis. In: Beneš, J., Pokorný, P. (Eds.): Bioarcheologie v České republice-Bioarchaeology in the Czech Republic. České Budějovice, Praha, 285-330.

SUGITA, S. 2007: Theory of quantitative reconstruction of vegetation I: pollen from large sites REVEALS regional vegetation composition. The Holocene 17/2, 229-241.

TOLAR, T., JACOMET, S., VELUŠČEK, A., CUFAR, K. 2010: Recovery techniques for waterlogged archaeological sediments: A comparison of different treatment methods for samples from Neolithic lake shore settlements. Vegetation History Archaeobotany 19/1, 53-68.

TÓTH, A. J., DARÓCZI-SZABÓ, L., KOVÁCS, Z. E., GÁL, E., BARTOSIEWICZ, L. 2010: In the Light of the Crescent Moon: Reconstructing Environment and Diet from an Ottoman-Period Deposit in Sixteenth to Seventeenth Century Hungary. In: Van Derwarker, A. M., Peres, T. M. (Eds.): Integrating Zooarchaeology and Paleoethnobotany: A Consideration of Issues, Methods, and Cases. Springer New York, New York, 245-280.

WANKEL, J. 1889: Náklo a Př́ikazy na Moravě. Časopis vlasteneckého spolku musejního v Olomouci 6, 49-58. 